\title{
The food composition of the symbiotic crab Pinnixa ratbbunae Sakai, 1934 (Brachyura: Pinnotheridae) from burrows of the spoon worm Urechis unicinctus (von Drasche, 1881) (Echiurida: Urechidae) in Vostok Bay of the Sea of Japan
}

\section{О составе пищи симбиотического краба Pinnixa ratbbunae Sakai, 1934 (Brachyura: Pinnotheridae) из нор эхиурид Urechis unicinctus (von Drasche, 1881) (Echiurida: Urechidae) в заливе Восток Японского моря}

\author{
Rudolf N. Burukovsky ${ }^{1}$, Ivan N. Marin ${ }^{2,3}$ \\ Рудольф Н. Буруковский ${ }^{1}$, Иван Н. Марин ${ }^{2,3}$
}

\footnotetext{
${ }^{1}$ Kaliningrad State Technical University, Sovetsky prosp., 11, Kaliningrad, 236022, Russia

${ }^{1}$ Калининградский государственный технический университет, Советский просп., 11, Калининград, 236022, Россия. E-mail: burukovsky@klgtu.ru

${ }^{2}$ A.N. Severtzov Institute of Ecology and Evolution of RAS, Leninsky prosp., 33, Moscow 119071, Russia. E-mail: coralliodecapoda@mail.ru, vanomarin@yahoo.com

${ }^{2}$ Институт проблем экологии и эволюции им. А.Н. Северцова РАН, Ленинский просп., 33, Москва, 119071, Россия.

${ }^{3}$ Biological Department, Altai State University, prospect Lenina, 61, Barnaul, 656049, Russia.

${ }^{3}$ Биологический факультет, Алтайский государственный университет, пр-т Ленина, 61, Барнаул, 656049, Россия.
}

KEY WORDS: Crustacea, Decapoda, Pinnixa rathbunae, Urechis, symbiosis, feeding, cooperation, Sea of Japan, Russian Federation.

КЛЮЧЕВЫЕ СЛОВА: Crustacea, Decapoda, Pinnixa rathbunae, Urechis, симбиоз, питание, кооперация, Японское море, Российская Федерация.

ABSTRACT. The food composition of the symbiotic crab Pinnixa rathbunae Sakai, 1934 inhabiting burrows of the spoon worm Urechis unicinctus (von Drasche, 1881) in Vostok Bay (part of the Peter the Great Bay) of the Sea of Japan is studied. Totally, 167 stomachs of crabs with carapace width from 5.9 to 11.8 $\mathrm{mm}$ were examined. Their stomach content includes inorganic and organic components. The inorganic component is represented by a mineral suspension of formless particles about $0.01-0.07 \mathrm{~mm}$ in size, i.e. pelites (aleurite-clay and fine silt) (the frequency $-100 \%$ ). Their further cementing (lithogenesis) inside the crab stomach is supposed: turning first into spheroid or pseudo-rhomboid formations of crystalline nature, with a stepped surface, forming bizarre splices $(0.07-0.15$ $\mathrm{mm}$ ) that can be attributed to large aleurites and then converted into a "particle aggregates" with the dimension up to $0.7^{\prime} 0.7 \mathrm{~mm}$ - a large psammophyte, i.e. large sand (37.1\%). Organic components consists of a suspension of unicellular organisms (97\%), lumps of filament identified as hyphae of fungi $(6.0 \%)$ and formless scraps (95.8-97\%) remaining fragments of connective tissue about $0.35-2.0 \mathrm{~mm}$ in size including ovoid bodies from $0.003-0.005 \mathrm{~mm}$ to 0.03 in length. Two latter components possibly develop on walls of the host burrow and crabs probably clean them off as a food object. At the same time, crabs can also feed on mucusous host's feeding net accumulating small phyto- and zooplankton. In this case, crabs probably perform the function of an attendant or "nurse of the burrow" and the relationship between $P$. rathbunae and Urechis can be considered as mutual, i.e. protocooperation.

How to cite this article: Burukovsky R.N., Marin I.N. 2018. The food composition of the symbiotic crab Pinnixa rathbunae Sakai, 1934 (Brachyura: Pinnotheridae) from burrows of the spoon worm Urechis unicinctus (von Drasche, 1881) (Echiurida: Urechidae) in Vostok Bay of the Sea of Japan // Arthropoda Selecta. Vol.27. No.4. P.319-324. doi: 10.15298/arthsel. 27.4.06

РЕЗЮМЕ. Исследовано питание симбиотических крабов Pinnixa rathbunae Sakai, 1934, обитающих в норах эхиурид Urechis unicinctus (von Drasche, 1881 ) в заливе Восток (часть залива Петра Великого) Японского моря. Всего исследовано содержимое 167 желудков крабов с шириной карапакса 5,911,8 мм. Содержимое желудков состоит из неорганических и органических компонентов. Неорганические компоненты представлены минеральной взвесью в виде бесформенных частиц размерами $0,01-$ 
0,07 мм, то есть пелитами (алеврито-глинистыми и мелкоалевритовыми илами) (частота встречаемости $100 \%$ ). В желудке краба они подвергаются цементированию (литогенез), превращаясь сначала в сфероидные или псевдо-ромбоидные образования кристаллической природы, со ступенчатой поверхностью, образуя причудливые сростки (0,15-0,07 мм), которые можно отнести к крупным алевритам. Далее они преобразуются в «камешек» с размерами до $0,7 \times 0,7$ мм - крупный псаммофит, т.е. крупный песок $(37,1 \%)$. Одновременно в каждом желудке присутствуют пищевые органические компоненты в виде взвеси одноклеточных организмов (97\%), бесформенных обрывков $(95,8-97 \%)$, напоминающих фрагменты соединительной ткани длиной 0,35-2,0 мм, содержащих яйцевидные тела длиной от 0,003-0,005 до 0,03 мм и клубки нитей, возможно, гифы грибов (6\%). Предполагается, что последние два компонента развиваются на стенках норы урехиса, и крабы способны счищать ее со стенок в качестве объекта питания. В тоже время, крабы, очевидно, питаются мукусоподобной ловчей сетью эхиуриды, в которой скапливается мелкий фито- и зоопланктон. В этом случае крабы выполняют функцию «санитара норы» и взаимоотношения между крабом и червем можно считать взаимовыгодными, т.е. протокооперацией.

\section{Introduction}

Symbiotic crabs of the genus Pinnixa White, 1846 (Brachyura, Pinnotheridae), or pea crabs, are smaller symbionts living inside the mantle cavity of mollusks, tubes of polychaetes, holes of sipunculans, echiuroids, and hemichordates; some species are known to be freeliving, although in this case, their lifestyle is poorly studied (e.g. McDermott, 2009). One of the species, Pinnixa rathbunae Sakai, 1934, is known along the Russian coast of the Sea of Japan inhabiting burrows of the spoon worm Urechis unicinctus (von Drasche, 1880) (Polychaeta: Echiura: Urechidae) (see Marin, 2013, 2016; Marin, Kornienko, 2014). The paper presents the study of the food composition and feeding features of symbiotic crab $P$. rathbunae and its relationships with the host in Vostok Bay of the Sea of Japan. The aim of the work is to attributed their "symbiont-host" system to one of known types of symbiotic relationships: sinoikia, commensalism, protocooperation or mutualism (after Beklemishev, 1951, Ecology.Portal.ru, 2018).

\section{Material and methods}

The material was collected with the help of a hand pump (yabbi-pump) in the Vostok Bay, 42 $54^{\prime} 32.2^{\prime \prime} \mathrm{N}$ $132^{\circ} 44^{\prime} 01.7^{\prime \prime} \mathrm{E}$ (part of the Peter the Great Bay), at 1415 July 2017. Totally, 167 stomachs seized from crabs in the process of biological analysis were studied. This volume of the material is considerably exceeded the level of the minimum necessary sufficiency for a repre- sentative assessment of stomach content [Cartes, Sarda, 1989].

The preliminary study showed that the methods previously used to describe the stomach content of 116 shrimp and 3 lobster species (see Burukovsky, 2009; Burukovsky, Medvedev, 2015; Burukovsky, Pushkin, 2016) are not applicable for $P$. rathbunae. It could be explained by high specialization of Pinnixa to the peculiarities of the forage reserve available in burrows of U. unicinctus. Moreover, the concept of the "food lump" could not be applied to this species as simply absent for $P$. rathbunae. It is also impossible to use the "full stomach content" for the reconstruction of the virtual "food lump" because the concept of the "portion of food" [Burukovsky, 2017] is also inapplicable to the object of our study. The evaluation of the "stomach fullness" is working for non-organic components of the food lump only (see below). As the result, it is difficult to estimate the actual impact of specific food objects in the food composition of the species and only a simple description of the stomach content with the determination of the frequency of various components is proved to be suitable for our study among the approaches used for other crustacean taxa. The frequency of the occurrence of each component is determined as a percentage to the whole volume of the stomach content.

The examination of the stomach content includes two stages: (1) the placement of the stomach on a slide, its opening under the binocular microscope MBS-10 $(\times 16)$ and identification of macroscopic fractions by four-grades ranking (see below); (2) washing out the stomach suspension containing microscopic organic and inorganic components and its examination in a drop of water under Levenhuk 320D320L Microscope (Zoom \& Joi) ( $\times 64-640)$ (as the microscope not possessing its own micrometer the components were measured with the maximum magnification of MBS-10). The organic component of the stomach content, unfortunately, could not be estimated by ranking as it looked like slurry in a drop of water after its washing out of opened stomach.

The four-grades ranking earlier developed by $\mathrm{Bu}-$ rukovsky [2009] for the investigation of feeding of deep water shrimps was transformed as follows: 0 points empty stomach except microscopic suspension; 1 point very small aggregations of mineral particles in the suspension; 2 points - large splices occupying at least the half of stomach cavity volume; 3 points - splices fill the entire stomach cavity (the description of "splices" is presented in the relevant section of the article below).

\section{Results}

\section{Morphology of crab stomach}

The stomach structure of $P$. rathbunae generally corresponds to other decapod crustaceans [Lockwood, 1968] but possesses some specific features. The stomach is almost equilaterally triangle in form, with rounded anterolateral corners, flat dorsally and convex ventrally, with the base connecting the frontal edge of car- 


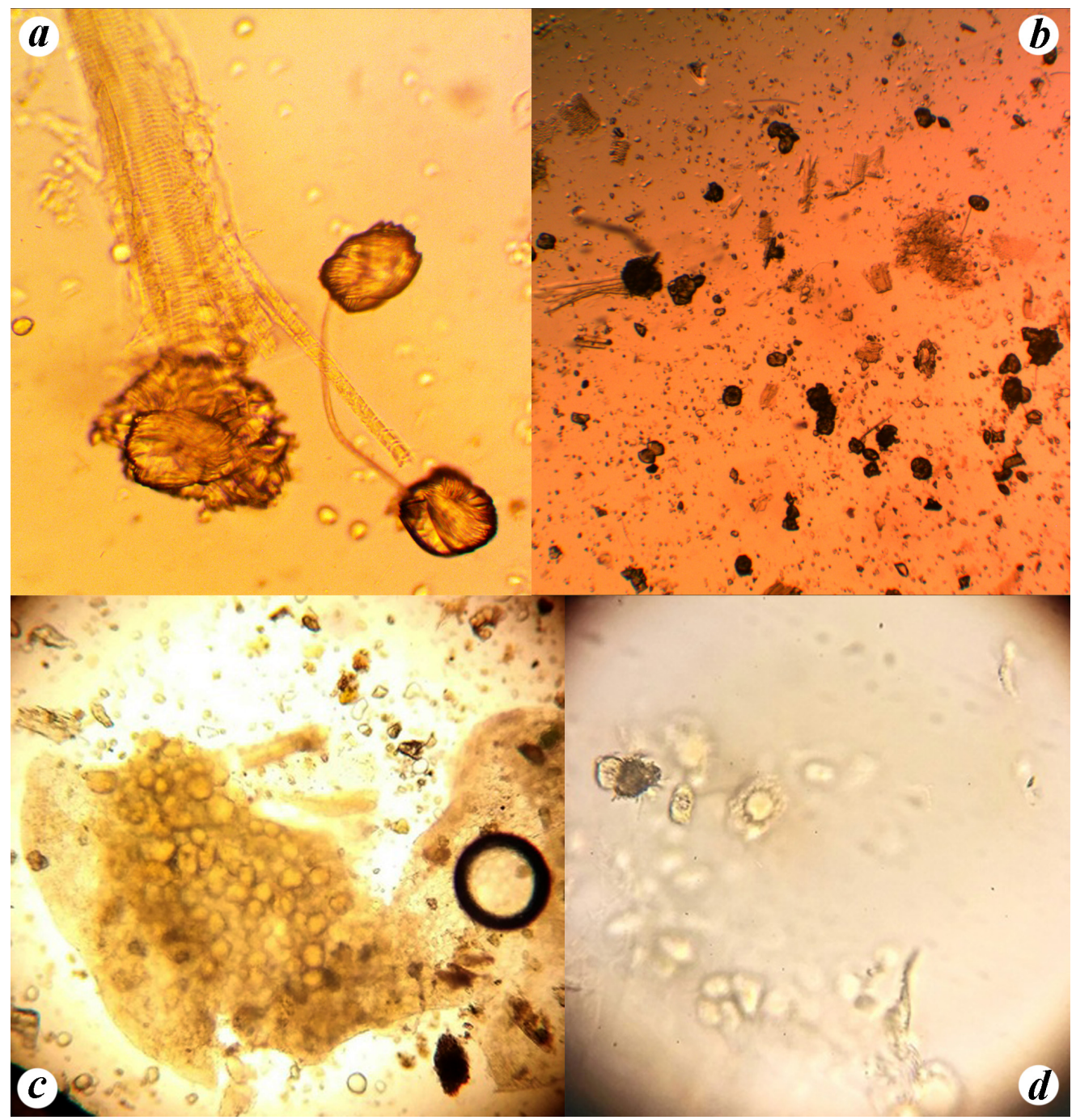

Fig. 1. Stomach content of crabs Pinnixa rathbunae from burrows of the spoon worm Urechis unicinctus: $a$ - mineral aggregates; $b-$ general view of the food bunch; $c$ - the film with ovoid bodies; $d$ - protozoan splice and cells.

Рис. 1. Содержимое желудка крабов Pinnixa rathbunae из нор Urechis unicinctus: $a$ - минеральные сростки; $b$ - общий вид участка пищи; $c$ - пленка с яйцевидными телами; $d$ - сросток и клетки простейших.

dial section. The longitudinal axis of the stomach is the height of this triangle in large individuals with the frontal edge (the base of the triangle) and the length (the height of the triangle) is estimated about $2.5-3.5 \mathrm{~mm}$ in length. The greatest depth of the stomach in its anterior third is about $1.5 \mathrm{~mm}$. A large number of separate large muscle fibers of striated musculature attach to the dorsal side of anterior and posterior parts of the stomach at right angles, and paired cecum diverticula reaching about 1.5 times of the length of the stomach can be observed; both structures are located in the dorsal part of the stomach, being twisted towards each other and coiled in a spiral. The walls of cecum are thick, with very narrow axial cavity appearing through their translucent walls; this cavity is never filled with any solid material. Possibly, the cells of the inner surface of cecum possess a glandular function.

\section{Description of the stomach content}

As it was reported above, no food lump in the usual sense were observed inside stomachs of $P$. rathbunae. The stomach content can be clearly divided into two permanently existing fractions: inorganic and organic. The inorganic components can also be subdivided into several groups, which were quantified with the abovementioned scale of the stomach fullness (granulometric characteristics of inorganic part of the stomach contents) (after Petelin, 1967).

The modified ranking of the stomach fullness is presented as follows: 0 points - a microscopic suspension consisting of formless mineral particles with the largest about $0.01-0.07 \mathrm{~mm}$ in size (mineral particles less than $0.01 \mathrm{~mm}$ were impossible to measure), i.e. pelites (aleurite-clay and fine silt); 1 point - spheroid or pseudo-rhomboid mineral formations (about 
$0.07-0.15 \mathrm{~mm}$ ) of clearly crystalline nature (large silts) with stepped surface occurring in the stomach together with pelites (Fig. 1a); sometimes forming bizarre conglomerates of several crystals; 2 points - large silt crystals filling at least half of the stomach; larger aggregations reaching the size of small psammophytes (0.25-0.1 mm) (according to Petelin, 1967); 3 points - the cavity of the stomach is filled with a "particle aggregates" presenting an agglomeration of a large number of spheroids or, more rarely, distorted rhomboids intricately related to each other; dimensions of the "particle aggregates" are close to internal dimensions of the stomach (about $0.7 \times 0.7 \mathrm{~mm}$ ) allowing to refer them to large psammophytes, i.e. large sand.

It appears that the process of the aggregates formation accompanying the process of crab feeding is continuous and cyclical. The aggregates reaching the size limited by internal dimensions of the stomach is excreted through the intestine. This process is well traced as excretory mineral aggregates are clearly visible through transparent proximal areas of the intestine. All forms of mineral particles from pelites to small psammophytes were found in all examined stomachs (the frequency is respectively $100 \%$ ) while the frequency of the aggregates occurrence is about $37.1 \%$. Other forms of mineral particles are also found in the suspension even when the stomach is filled with a "particle aggregates". Probably, the process of the aggregates formation and outward excretion of the clusters of mineral particles are continuous. It likely requires a strong stomach musculature to avoid cementing of mineral particles. The same process of cementing occurs in natural silts belonging to the group of loose, friable sedimentary rocks consisting mainly of grains of quartz, feldspar, mica and other particles of $0.05-0.1 \mathrm{~mm}$ in size [Aleurites, Geological Dictionary, 1988; Wikipedia]. This process of changing, including the cementing of silts, is called lithogenesis. Probably, the micro-processes occurring with mineral particles inside the stomach of P. rathbunae are similar to the natural processes in mineral world, representing a kind of lithogenesis.

The non-organic (mineral) components of the stomach content also include diatom and foraminiferan shells without organic matter. Diatoms (similar to Navicula (most often), Coscinodiscus and Nizschia) are observed with the frequency of $4.2 \%$. Diatom shells are $0.01-$ $0.03 \mathrm{~mm}$ in size that is comparable to fine silts. The only observed foraminiferan shell consists of three chambers being comparable in size to fine aleurites (the frequency is about $0.6 \%$ ) (Tab. 1).

\section{Organic components (food items)}

Usually (in about $97 \%$ of specimens) some oval cells with a large nucleus and often with numerous small vacuoles and flagella, perhaps belonging to Protista, are observed $(\times 640)$ inside the crab stomachs (Fig. 1d). The dimensions of these cells are in the range of $0.003-0.005 \mathrm{~mm}$ comparing with the smallest measurable mineral particles. The source and way of their appearance inside the stomachs of $P$. rathbunae are not clear, but it is possible that they appeared by the crab feeding on the mucusous host's net (see below).

The same frequency $(95.8 \%)$ is observed for the formless scraps resembling fragments of connective tissue with the length varying from 0.35 to $2 \mathrm{~mm}$. Several times such fragments appears as smooth and slightly thickened edges with multicellular structure. Usually, the "tissue" contains numerous opaque "ovoid bodies" (making impossible to detect any inner contents) ranging from $0.003-0.005$ to $0.03 \mathrm{~mm}$ in length (Fig. 1c). The number of "ovoid bodies" varies for each fragment of the "tissue" — from a single body to completely covered by these "bodies" when the tissue is almost concealed. Sometimes, large "ovoid body" with several neighboring significantly smaller ones are observed. Moreover, most of large "bodies" easily detaches in a drop of water resembling a comparison with something like a "fruit body" leaving the "fabric" after maturation.

Yellowish-olive colored aggregations of very finegrained consistency reaching $0.7 \times 1.4 \mathrm{~mm}$ weaved by filament probably fastening this formation are observed inside crab stomachs with the frequency about $21.6 \%$.

The lumps of filaments attributed to hyphae of fungi are found with the frequency about $6 \%$. However, the frequency of this food object is understated as such fine-grained structures were poorly discernable even with the maximal microscope magnification $(\times 640)$.

Table 1. Stomach content of Pinnixa rathbunae from burrows of Urechis unicinctus. Таблица 1. Содержимое желудков Pinnixa rathbunae из нор Urechis unicinctus.

\begin{tabular}{|l|c|}
\hline \multicolumn{1}{|c|}{ Food component } & $\begin{array}{c}\text { The frequency of } \\
\text { occurrence, } \%\end{array}$ \\
\hline The clusters of small formless mineral particles (pelites and alevrites) & 100 \\
\hline Separate cells, probably Protista & 97.0 \\
\hline Formless scraps resembling fragments of connective tissue with ovoid bodies & 95.8 \\
\hline "Particle aggregates" (large splices of mineral formations, i.e. psammophytes) & 37.1 \\
\hline Fine-grained yellowish-olive mass (aggregations weaved by filament) & 21.6 \\
\hline Lumps of filament (hyphae of fungi (?)) & 6.0 \\
\hline Shells of diatoms & 4.2 \\
\hline Foraminifera & 0.6 \\
\hline
\end{tabular}




\section{Discussion}

The problem of symbiotic associations between crabs of the family Pinnotheridae and their hosts is relatively well described in extensive literature and its review is beyond the main aim of this work. In any case, it should be noted that these symbiotic associations include a wide range of different relationships: from physiological (e.g. Grove et al., 2000) to widely ecological (e.g. Alves, Pezzuto, 1998; McDermot, 2005). At the same time, the trophic connections between pinnotherid crabs and their hosts have been investigated irregularly and poorly in comparison to other crustacean taxa.

For example, crabs of the genus Pinnotheres Bosc, 1801 (Pinnotheridae) living inside bivalves and ascidians were observed to feed on mucus secreted on gills of their hosts [Becker, Türkay, 2017] showing that these crabs are true commensals. The study of food composition is quite reliably described in endocommensal Pinnixa tumida Stimpson, 1858 (Pinnotheridae) living in the posterior sections of digestive tract of burrowing holothurian Paracaudina chilensis (Müller, 1850) (Echinodermata: Holothuroidea: Caudinidae) [Takeda et al., 1997]. In the laboratory, crabs were offered with a wide variety of food but they chose a suspension of particles collected near the shore by plankton net and mucus secreted by digestive system of their host [Takeda et al., 1997]. At the same time, a number of examples of "in vitro" experiments show that the real food composition of experimental animals is analogous but not adequate to their diet "in situ".

The food composition of Pinnixa, which possibly only cohabit burrows of their hosts is virtually unknown (e.g. McDermott, 2009). Anker et al. [2005] reviewed ecological features and species composition of symbionts associated with 15 species of spoon worms in Atlantic and Pacific oceans with the description of feeding mechanism of Urechis worms. These echiurans are active filter feeders as they possess with a relatively short proboscis that is unsuitable for collecting of detritus from surface around their burrows. However, they secrete mucus by the glands lying around the base of the proboscis and form a funnel-shaped net that is eaten after filling with food particles [Fisher, MacGinitie, 1928]. The net is formed attaching to the base of the proboscis proximally and to walls of the burrow close to exit. Reversible peristaltic contractions of worm musculature pump water through the net, making thus possible to catch particles up to $0.04 \mathrm{~mm}$.

Pinnotherid crab Scleroplax granulata Rathbun, 1894 inhabiting burrows of the spoon worm Urechis caupo Fisher et MacGinitie, 1928 (Polychaeta: Echiura: Urechidae) in California has been observed to feed on mucus of the feeding net of their hosts as well as particles captured by the net [Anker et al., 2005]. The burrows of this spoon worm species are inhabited by symbiotic crabs Pinnixa franciscana Rathbun, 1918 and Pinnixa schmitti Rathbun, 1918 (Pinnotheridae)
[Zmarzly, 1992; Campos et al., 2009; Campos, Campos, 2012]. Our results indicate that $P$. rathbunae living in burrows of $U$. unicinctus in the Vostok Bay of the Sea of Japan feeds on the feeding net produced by the host spoon worm. This feeding style can help to explain the presence of large quantities of microscopic material of biological origin and the smallest mineral particles with all their transformations inside the crabs' stomachs. The main food object of $P$. rathbunae is a fine-grained substance, probably belonging to fungi, and tissue-like scraps with numerous "fruit bodies" that were unlikely to be filtered from the water by a mucusous feeding net of their host. It also could be assumed that the above-mentioned tissue-like structure with "fruiting bodies" develops on the walls of the burrows and crabs clean it off from the walls using as a food object. As a working hypothesis, it is possible to assume that crabs can perform the function of the attendant or "nurse" within the shelter burrows and the relationship between crab and its echiurian host can be considered as a mutual protocooperation.

\section{Acknowledgements}

The study was financially supported by the Russian Foundation of Fundamental Researches (RFFR) (grant 17-04-00413A "Symbiotic crabs of the genus Pinnixa (Pinnotheridae) in Russian waters of the Sea of Japan: diversity, features of ecology and relationships with their hosts" and 18-04-01093 A "Large burrowing crustaceans (Callianassidae and Upogebiidae) and their symbionts: diversity and trophic interaction"). Authors are very grateful to the staff of the biological scientific station "Vostok" of NSCMB FEB RAS (Vladivostok, Russia) and personally Konstantin Dudka for the help during the field sampling; to E.A. Poddueva and K.A. Kobyakov for the technical processing of the material during the analysis and to E. Pakhomov and C. Becker for the informational support during the study. We are thankful to K.A. Kobyakov and S.A. Sudnik for the photo of the stomach content.

\section{References}

[Alevrites. Geological dictionary]. 1988. Vol.1. Leningrad: Nedra. 486 p.] [in Russian].

Alevrites. Wikipedia. [Electronic resource ] https://ru.wikipedia.org/ wiki/Алеврит [Date of last to address on 08/07/2018] [in Russian]

A summary of lectures on the course "Stadial analysis of lithogenesis" [Electronic resource] https://studfiles.net/preview/6449577/ page:8 [Date of last to address on 08/07/2018] [in Russian]

Alves A.S., Pezzuto P.R. 1998. Population dynamics of Pinnixa patagoniensis Rathbun, 1918 (Brachyura: Pinnotheridae) a symbiotic crab of Sergio mirim (Thalassinidea: Callianassidae) in Cassino Beach, Southern Brazil // Marine Ecology. Vol.19. No.1. P.37-51.

Anker A., Murina G.-V., Lira C., Caripe J.A.V., Palmer A.R., Jeng M.-Sh. 2005. Macrofauna associated with echiuran burrows: A review with new observations of the innkeeper worm, Ochetostoma erythrogrammon Leuckart and Rüppel, in Venezuela // Zoological Studies. Vol.44. No.2. P.157-190. 
Becker C., Türkay M. 2017. Host specificity and feeding in European pea crabs (Brachyura, Pinnotheridae) // Crustaceana. Vol.90. No.7-10. P.819-844.

Beklemishev V.N. 1951. [On the classification of biocenological (symphysiological) bonds] // Bulleten' Moskovskogo Obshestva Ispytateley Prirody, Otdelenie Biologii [Bulletin MOIP]. Vol.56. No.5. P.3-30 [in Russian with English abstract].

Burukovsky R.N. 2009. [Food and food relationships of shrimp]. Kaliningrad: Izdatelstvo KGTU. 408 p. [in Russian]

Burukovsky R.N. 2017. [Shrimps of West African waters (geographical distribution, regularities of horizontal and vertical distribution, life forms and ecological structure of taxocenes)]. $\mathrm{SPb}$ : Prospect Nauki Publ. 512 p. [In Russian with English abstract]

Burukovsky R.N., Medvedev G.V. 2015. [The composition of the food of deep-sea lobster Polycheles suhmi (Bate 1878) and Polycheles sculptus Smith 1880 (Crustacea, Decapoda, Polychelidae)] // Zoologicheskiy Zhurnal. Vol.94. No.7. P.1-10 [in Russian with English abstract].

Burukovsky R.N., Pushkina N.S. 2016. [Some features of biology and food composition in the lobster Acantharctus posteli (Decapoda, Crustacea, Scyllarinae) (West Africa)] // Zoologicheskiy Zhurnal. Vol.95. No.6 P.660-668 [in Russian with English abstract].

Campos E., Campos A.R., Manriquez I. 2009. Intertidal thalassinidean shrimps (Thalassinidea, Callianassidae and Upogebiidae) of the west coast of Baja California, Mexico: annotated checklist, key for identification, and symbionts // Crustaceana. Vol.82. P.1249-1263.

Campos E., Campos A.R. 2012. The intertidal brachyuran crabs from estuaries of the west coast Baja California, Mexico (Crustacea: Brachyura) // Marine Biodiversity Records. Vol.5; e117. doi:10.1017/S1755267212000966

Cartes J.E., Sarda F. 1989. Feeding ecology of the deep-water aristeid crustacean Aristeus antennatus // Marine EcologyProgress Series. Vol.54. P.229-238.

[Geological dictionary]. 1988. T.1. Leningrad: Nedra. 486 p. [in Russian]

Fisher W.K., MacGinitie G.E. 1928. XVII. The natural history of an echiuroid worm // Annals and Magazine of Natural History. Ser.10. Vol.1. P.204-213.
Grove M.W., Finelli Ch.M., Wethey D.S., Woodin S.A. 2000. The effects of symbiotic crabs on the pumping activity and growth rates of Chaetopterus variopedatus // Journal of Experimental Marine Biology and Ecology. No.246. P.31-52.

Lockwood A.P.M. 1968. Aspects of the Physiology of Crustacea // University review in Biology. No.8. Edinbourgh and London: Oliver \& Boyd. 328 pp.

McDermott J.J. 2005. Biology of the brachyuran crab Pinnixa chaetopterana Stimpson (Decapoda: Pinnotheridae) symbiotic with tubicolous polychaetes along the Atlantic coast of the United States, with additional notes on other polychaete associations // Proceedings of the Biological Society. Washington. Vol.118. No.4. P.742-764.

McDermott J.J. 2009. Hypersymbioses in the pinnotherid crabs (Decapoda: Brachyura: Pinnotheridae): a review // Journal of Natural History. Vol.43. Nos.13-14. P.785-805.

Marin I.N. 2013. Atlas of Decapod Crustaceans of Russia. Moscow: KMK Scientific Press. 145 pp.

Marin I.N., Kornienko E.S. 2014. The list of Decapoda species from Vostok Bay Sea of Japan // Biodiversity and Environment of Far East Reserves. Vol.2. P.50-72.

Marin I.N. 2016. The species composition and ecological features of pea crabs of the genus Pinnixa White, 1846 (Brachyura: Pinnotheridae) in Peter the Great Bay, the Sea of Japan // Russian Journal of Marine Biology. Vol.42. No.2. P.139-145.

Petelin V.P. 1967. [Granulometric analysis of marine bottom sediments]. Moscow: Nauka. 11 p. [in Russian]

[Symbiosis (protocooperation and mutualism)]. Ecology. Portal Ru. http://ecology-portal.ru/publ/3-1-0-111 [Date of the last renewal - 11.07.2018] [in Russian]

Takeda S., Tamura S., Washio M. 1997. Relationships between the pea crab Pinnixa tumida and its endobenthic holothurian host Paracaudina chilensis // Marine Ecology-Progress Series. Vol.149. P.143-154.

Zmarzly D.L. 1992. Taxonomic review of pea crabs in the genus Pinnixa (Decapoda: Brachyura: Pinnotheridae) occurring on the California shelf, with descriptions of two species // Journal of Crustacean Biology. Vol.12. No.4. P.677-713.

Responsible editor V.A. Spiridonov 